\title{
Field Wave Gaging Program, Wave Data Analysis Standard
}

by Marshal D. Earle

Neptune Sciences, Inc.

11341 Sunset Hills Road

Reston, VA 22090

David McGehee, Michael Tubman

U.S. Army Corps of Engineers

Waterways Experiment Station

3909 Halls Ferry Road

Vicksburg, MS 39180-6199

Final report

Approved for Public Release; Distribution is Unlimited

Prepared for U.S. Army Corps of Engineers

Washington, DC 20314-1000 